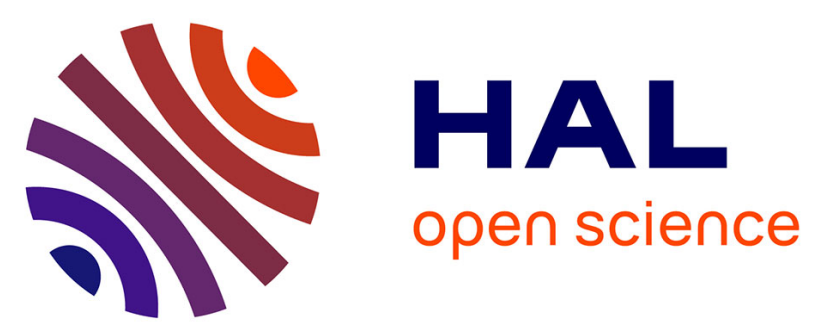

\title{
A HS-SPME-GC-MS analysis of IR heated wood: Impact of the water content on the depth profile of oak wood aromas extractability
}

Charlie J. Duval, Karine Gourrat, Patrick Perre, Andréi Prida, Régis D. Gougeon

\section{To cite this version:}

Charlie J. Duval, Karine Gourrat, Patrick Perre, Andréi Prida, Régis D. Gougeon. A HS-SPME-GCMS analysis of IR heated wood: Impact of the water content on the depth profile of oak wood aromas extractability. Food Research International, 2013, 54 (1), pp.277-284. 10.1016/j.foodres.2013.07.008 . hal-00866391

\section{HAL Id: hal-00866391 \\ https://hal.science/hal-00866391}

Submitted on 29 May 2020

HAL is a multi-disciplinary open access archive for the deposit and dissemination of scientific research documents, whether they are published or not. The documents may come from teaching and research institutions in France or abroad, or from public or private research centers.
L'archive ouverte pluridisciplinaire HAL, est destinée au dépôt et à la diffusion de documents scientifiques de niveau recherche, publiés ou non, émanant des établissements d'enseignement et de recherche français ou étrangers, des laboratoires publics ou privés. 


\title{
A HS-SPME-GC-MS analysis of IR heated wood: Impact of the water content on the depth profile of oak wood aromas extractability
}

\author{
Charlie J. Duval a , Karine Gourrat ${ }^{b}$, Patrick Perre ${ }^{c}$, Andréi Prida ${ }^{\text {d }}$, Régis D. Gougeon ${ }^{\text {a,* }}$

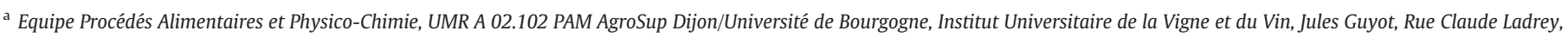 \\ BP 27877, 21078 Dijon Cedex, France \\ b UMR FLAVIC, Plate-Forme Lipides-Arômes, INRA 17 rue de Sully, BP 86150, 21065 Dijon, France \\ c Ecole Centrale Paris, Laboratoire LGPM, Grande Voie des Vignes, 92295 Châtenay-Malabry, France \\ d Tonnellerie Seguin Moreau, Z.I. Merpins, B.P. 94, 16103 Cognac, France
}

\section{A R T I C L E I N F O}

\section{Article history:}

Received 27 February 2013

Accepted 2 July 2013

Available online 11 July 2013

\section{Keywords:}

Oak wood

HS-SPME

GC-MS

Infrared heat source

Volatile compounds

\begin{abstract}
A B S T R A C T
Controlled and reproducible IR heat treatments were applied to oak wood surfaces in order to establish a depth-profiled picture of the extractability of volatile compounds, with particular emphasis on the impact of the initial water content. Headspace-solid phase microextraction-gas chromatography coupled to mass spectrometry (HS-SPME-GC-MS) has been used to compare the concentrations of six aroma compounds (vanillin, furfural, eugenol; guaiacol and cis- and trans-whisky lactones) in hydroalcoholic extracts of series of slices representative of the first $8 \mathrm{~mm}$ of the wood facing the IR source. Results have shown that although water is supposed to have a delaying effect with respect to the thermal degradation of wood macromolecules, it can favor heat transfers and thus promote higher-than-expected transient local temperatures in a soaked wood. Yet, distinct behaviors could be observed between thermally-generated compounds (vanillin and guaiacol), where adsorbed water seemed to prevent the thermal degradation of the parent macromolecule, and thermally-degraded compounds such as eugenol where the presence of water would balance the compound degradation through a more efficient extraction process of this biogenesis molecule. Furfural exhibited a more complex behavior since its production as a result of hemicellulose degradation was thermally-favored in the presence of adsorbed water. Finally, whatever the applied heat flux and regardless of the initial water content, temperatures experienced by the wood deeper than $4 \mathrm{~mm}$, were lower than $160{ }^{\circ} \mathrm{C}$, which meant that beyond that depth, the initial wood composition was unaffected.
\end{abstract}

(c) 2013 Elsevier Ltd. All rights reserved.

\section{Introduction}

Barrels are used since antiquity as wine containers, and the process of barrel making did not evolve much during a long period. However, wood/ wine interactions were the subject of numerous studies over the past thirty years, since it appeared that barrels could also be considered as "active packaging". Barrel aging allows microoxygenation of wine, which in turn permits an aroma evolution (Cutzach, Chatonnet, \& Dubourdieu, 1999; Ferreira, Jarauta, López, \& Cacho, 2003; Jarauta, Cacho, \& Ferreira, 2005) and color stabilization (Fulcrand, Benabdeljalil, Rigaud, Cheynier, \& Moutounet, 1998; Fulcrand, Dos Santos, Sarni-Manchado, Cheynier, \& Favre-Bonvin, 1996; Rentzsch, Schwarz, \& Winterhalter, 2007). Woodrelated sensory properties acquired by the wine depend on many factors such as the various wood/wine exchange equilibria including those resulting from sorption mechanisms by the wood, the barrel-making process, and the wine composition itself, but the most important one is the

\footnotetext{
* Corresponding author. Fax: + 33380396265.

E-mail addresses: lilo.duval@gmail.com (C.J. Duval), karine.gourrat@dijon.inra.fr (K. Gourrat), patrick.perre@ecp.fr (P. Perre), aprida@seguin-moreau.fr (A. Prida), regis.gougeon@u-bourgogne.fr (R.D. Gougeon).
}

wood composition (Garde-Cerdán \& Ancín-Azpilicueta, 2006; Jarauta et al., 2005; Perez-Prieto, López-Roca, Martínez-Cutillas, Pardo Mínguez, \& Gómez-Plaza, 2002; Towey \& Waterhouse, 1996). The wood composition depends directly on its geographical origin (Ancín, Garde, Torrea, \& Jimenez, 2004; Del Alamo Sanza, Nevares Dominguez, Carcel Carcel, \& Navas Gracia, 2004; Mosedale, Puech, \& Feuillat, 1999; Perez-Prieto et al., 2002; Prida \& Puech, 2006; Waterhouse \& Towey, 1994), its species (Feuillat, Keller, Sauvageot, \& Puech, 1999; Mosedale, Feuillat, Baumes, Dupouey, \& Puech, 1998) and its position in the tree itself (Doussot, Pardon, Dedier, \& De Jéso, 2000; Gougeon et al., 2009; Prida \& Puech, 2006). It is on this chemical basis that all of the successive steps of the barrel-making process will modulate the extractible content of the wood that will finally be in contact with the wine.

Seasonings result in a loss of tannins and either an up- or downmodulation of volatile compounds; for example the concentration of the two whisky lactone isomers generally increases during the seasoning (Cadahía, Fernández de Simón, \& Jalocha, 2003; Cadahía, Muñoz, Fernández de Simón, \& García-Vallejo, 2001; Doussot, De Jéso, Quideau, \& Pardon, 2002). Then the heating takes place in two steps; first the bending process during which the staves are heated just enough to allow for the formation of the barrel and the second 
step called toasting, which is designed to fine tune concentrations in volatile compounds by modulating the degradation of wood macromolecules. Literature shows that there are various definitions for the "intensity" of heating that are applied in studies which aimed at reproducing genuine cooperage conditions (Chatonnet \& Boidron, 1989; Hale, Mccafferty, Larmie, Newton, \& Swan, 1999; Kim, Kim, Kim, \& Yang, 2006), thus making it difficult to get clear correlations between heating temperatures and concentrations in extractible compounds. But general trends do exist for heat treatments of dry woods, which concern mainly the evolution of extractable volatile compounds (Duval et al., 2013).

In contrast, unambiguous definitions of heat fluxes effectively experienced by the wood surface during heating are yet to be proposed. Indeed, most of the studies on the effect of aging in oak barrel have used real or model wines aged in barrels or exposed to oak chips or staves. In any case, wood samples were either heated traditionally using a wood fire (Ancín et al., 2004; Cutzach et al., 1999; González-Marco, JiménezMoreno, \& Ancín-Azpilicueta, 2008; Spillman, Pollnitz, Liacopoulos, Skouroumounis, \& Sefton, 1997) or in a laboratory, using an oven with temperature regulation (Alañón, Rubio, Díaz-Maroto, \& Pérez-Coello, 2010; Fernández de Simón, Cadahía, Del Álamo, \& Nevares, 2010) or a vertically oriented electric plate to simulate the wood fire source (Canas, Grazina, Belchior, Spranger, \& De Sousa, 2000). As a consequence, various heating processes have been implemented which are characterized by a great variability of temperature conditions. In the case of the traditional barrel making process, the heat source is a wood fire (Chatonnet \& Boidron, 1989) which means that the heat distribution at the surface of the wood is highly variable, in space and in time (Chatonnet, Boidron, \& Pons, 1989). Furthermore, heat treatments definitely vary from one cooper to the other. If an oven is used, the treatment affects all the surface of the sample, which in turn has an impact on heat fluxes in the wood sample. In such an experimental setup, the temperature is rather well controlled (Duval et al., 2013), but likely differs from a traditional heating process where the staves experience a temperature gradient ranging from the highest temperature on the exposed side of the barrel to a temperature close to ambient on the opposite side. As a consequence, one can expect concentration gradients of temperature-sensitive compounds within the width of the staves. Therefore, for a given width of wine impregnation, which has been shown to be up to $8 \mathrm{~mm}$ in model wine conditions (Sarni, Rabier, \& Moutounet, 1990), different heat treatments may lead to different extractabilities of wood-related aromas. As shown by Chatonnet and Boidron (1989), concentrations in volatile compounds that can be extractible by model wine vary along the width of the staves and depend on the applied heat intensity. Most of the analyzed compounds show for instance an increase of their concentrations when going from the $[0 ; 1 \mathrm{~mm}]$ to the $[1 ; 2 \mathrm{~mm}]$ widths away from the heated surface. This is explained by lower thermal self-degradations of compounds at locations that are away from the heat source. However, concentrations measured at depths of $[2 ; 3 \mathrm{~mm}]$ are generally lower than those measured in the range $[1 ; 2 \mathrm{~mm}]$.

Finally, and so far, the vertical plate setup (Canas et al., 2000) probably matches the closest conditions to the wood fire. However, no heat flux characteristics were provided, and variations of concentrations along the depth were not discussed.

This study is a follow-up of a previous paper where we had compared the impact of the water content of wood, modulated by bending process, on concentrations of six aroma compounds in hydroalcoholic extracts of heated oak wood chips. The soaking step is characteristic of the AquaFlex process developed and sometimes used by the cooperage industry. It consists in soaking wood staves in hot water in order to plasticize fibers for the bending process, without fire exposure (Duval et al., 2013). In this study and for the first time, we report on the use of an infrared heat source to simulate a fire source, with a constant and measurable heat flux experienced by the wood. Furthermore, and in order to take into account temperature gradients within the depth of the wood, we report on concentration gradients within the first $8 \mathrm{~mm}$ of wood exposed to the IR source, either previously soaked in hot water or airdried.

\section{Materials and methods}

\subsection{Wood samples}

All wood samples were from a single 400-year old Quercus petreae tree from the "forêt des beaux Monts" (Oise, France), provided by Tonnellerie Seguin Moreau (Cognac, France). They were taken from staves after natural seasoning for two years.

\subsection{Heat treatment}

Small wood boards with the same geometric shape ( $\mathrm{L}, \mathrm{l}, \mathrm{w}=$ $220 \mathrm{~mm}, 60 \mathrm{~mm}, 28 \mathrm{~mm}$ ) were used for heat treatments. Temperature conditions were designed after measurements of heat fluxes during the real barrel making process for two types of toasting: traditional medium intensity and AquaFlex processes, thereafter referred to as "strong" and "light" intensities, respectively. Heat treatments were applied with an adjustable infrared heat source. In order to insure reproducible experiments, the heat flux intensity was objectively determined with the aid of an aluminum plate whose exposed surface was coated with carbon black. This ensures an emissivity close to the unit, which is representative of the wood surface. The energy balance of this plate reads

$\rho c_{p} V \frac{d\langle T\rangle}{d t}=S_{r} q_{r}+\operatorname{Sh}\left(T_{\infty}-T_{S}\right)$

Where $\rho$ is the plate density, $c_{p}$ its specific heat, $\langle T\rangle$ the averaged temperature of the plate, $\mathrm{V}$ the volume of the plate and $\mathrm{S}_{\mathrm{r}}$ the surface exposed to radiation, $\mathrm{q}_{\mathrm{r}}$ the radiative flux, $\mathrm{h}$ the convective heat transfer coefficient, $S$ the exchange surface of the plate, $T_{\infty}$ the external temperature and $T_{S}$ the surface temperature.

During the initial transient period, i.e. while the plate temperature remains close to the ambient temperature, the energy loss by convection vanishes. The energy balance is then very simple: the energy supplied to the plate by radiation is fully converted into temperature increase.

Aluminum was chosen because of its high conductivity. This allows the characteristic time of thermal diffusion $\tau$ to be very short:

$\tau=\frac{\rho c_{\mathrm{p}} \mathrm{t}^{2}}{\lambda}$.

In Eq. (2), $t$ is the half-thickness of the sample and $\lambda$ the thermal conductivity. Using values for aluminum $\left(\rho=2700 \mathrm{~kg} \cdot \mathrm{m}^{-3}, \mathrm{c}_{\mathrm{p}}=\right.$ $880 \mathrm{~J} \cdot \mathrm{kg}^{-1} \cdot \mathrm{K}^{-1}$ and $\left.\lambda=190 \mathrm{~W} \cdot \mathrm{m}^{-1} \cdot \mathrm{K}^{-1}\right)$ and with a thickness of $8 \mathrm{~mm}$, the time constant $\tau$ equals $0.2 \mathrm{~s}$. This value is very small and allows a full range of time for which the temperature may be supposed to be constant throughout the plate and close to the external temperature.

Consistently, the averaged temperature was measured by a thermocouple inserted in the plate and the radiative flux was evaluated from the temperature slope during the first $30 \mathrm{~s}$, with the aluminum sheet placed at $22 \mathrm{~cm}$ from the IR source. For the moderate intensity, the slope had a value between 0.2149 and 0.222 , whereas for the strong intensity it had a value between 0.2766 and 0.2895 . Using Eq. (1), these values correspond to radiative fluxes of 4.17 and $5.46 \mathrm{~kW} \cdot \mathrm{m}^{-2}$ respectively.

Therefore, the strong intensity corresponded to a heat flux about 1.3 times higher than that for the light intensity. Controls of heat fluxes were done before and after each treatment. Both sides of the wood boards were exposed to air and temperatures in the wood were recorded at 2, 4 and $8 \mathrm{~mm}$ depths (Fig. 1). Each treatment was 
repeated three times, thus providing us with three sets of boards for a given condition. Before heat treatments wood boards were either soaked in hot water $\left(90^{\circ} \mathrm{C}\right)$ for $20 \mathrm{~min}$, or kept dry. This study is a model experiment of conditions applied in cooperage industries. Averages of temperature recordings for every condition are presented in Fig. 2.

\subsection{Extraction}

Using an electrical knife to reduce local overheating, four successive 2-mm thick pieces of wood were cut out of each of the three boards for a given condition, in order to assess volatile concentration gradients through the first $8 \mathrm{~mm}$ exposed to heat (Fig. 1). These twelve pieces were then ground down to $<345 \mu \mathrm{m}$ powders with an electric coffee grinder. For each sample, 10 grinding cycles of $5 \mathrm{~s} \mathrm{sep-}$ arated by periods of $15 \mathrm{~s}$ were applied in order to avoid overheating of the wood. The obtained powders were kept at $4{ }^{\circ} \mathrm{C}$ until the extraction.

Volatile compounds were extracted using the following method. Sawdust samples were soaked in hydroalcoholic solution (13\% ethanol, $5 \mathrm{~g} / \mathrm{L}$ tartaric acid and $\mathrm{pH}$ adjusted to 3.2 with sodium hydroxide) at a concentration of $30 \mathrm{~g} / \mathrm{L}$ for $48 \mathrm{~h}$ at $25^{\circ} \mathrm{C}$ in darkness. After filtration on $0.22 \mu \mathrm{m}$ nitrocellulose filters, 3,4-dimethylphenol was added to the filtrate as internal standard at a concentration of $5 \mathrm{mg} / \mathrm{L}$.

\subsection{Volatile compounds analysis}

$10 \mathrm{~mL}$ of model wine were placed in a $20 \mathrm{~mL}$ sealed headspace vial (Supelco, Bellefonte, USA). Headspace vials were then placed in the agitator/incubator of an automatic headspace sampler (GERSTEL MPS 2, Gerstel Inc., Mülheim an der Ruhr, Germany) and incubated at $70{ }^{\circ} \mathrm{C}$ for $10 \mathrm{~min}$ (incubation time) in order to promote volatile compounds in the headspace. Extractions were realized by immersing a DVB-CAR-PDMS fiber in the headspace for $60 \mathrm{~min}$ (extraction time). After each extraction, extracted compounds were desorbed at $260{ }^{\circ} \mathrm{C}$ for 7 min (Carrillo, Garrido-López, \& Tena, 2006) in the injection port of an HP 6890GC equipped with an MSD 5973 mass detector (Agilent Technologies, Palo Alto, CA). Calibration solutions were processed in the same way using $10 \mathrm{~mL}$ of standard solutions, with concentrations ranging from 0 to $1 \mathrm{mg} \cdot \mathrm{g}^{-1}$ of wood depending on the analyzed compound. We have checked with highly aroma-concentrated calibration samples either alone or in mixture and there were no competition effects between aromas or as a result of the high ethanol level. Chromatographic analyses were done in triplicate.

Volatile compounds (eugenol, guaiacol, furfural, vanillin, cis- and trans-whisky lactone) were purchased from Sigma-Aldrich and used as received.

\subsection{Chromatographic conditions}

Separation was done with a CP-WAX 52CB column (30 m $\times 0.32 \mathrm{~mm}$ I.D. with a $0.25 \mu \mathrm{m}$ polyethylene phase). The oven program started at an initial temperature of $40{ }^{\circ} \mathrm{C}$ for $3 \mathrm{~min}$. Temperature was then increased at a rate of $7{ }^{\circ} \mathrm{C} \mathrm{min}-1$ up to $230{ }^{\circ} \mathrm{C}$. A $0.8 \mathrm{~mm}$ I.D. liner was used and maintained at $270{ }^{\circ} \mathrm{C}$ with a $1: 10$ split ratio. The carrier gas was helium at $1.0 \mathrm{~mL} \cdot \mathrm{min}^{-1}$ (99.996\%). Ionization was performed by electronic impact (EI), setting the electron multiplier to $1600 \mathrm{eV}$. Temperatures used were $200{ }^{\circ} \mathrm{C}$ for the trap, $60{ }^{\circ} \mathrm{C}$ for the manifold, and $280{ }^{\circ} \mathrm{C}$ for the transfer line. Compounds were quantified in selected ion storage (SIS) mode, selecting the appropriate ion masses for each compound: furfural $(95+96)$, guaiacol $(109+124)$, whisky lactone (99), eugenol (164), 3,4-dimethylphenol $(107+122)$, and vanillin $(151+152)$. We have checked that each of these single ion masses was sufficient for the selective detection of the corresponding compound in our model solutions. All of our analyte concentrations were above LOQs reported in the literature for the same experiments (Carrillo et al., 2006), except for guaiacol.

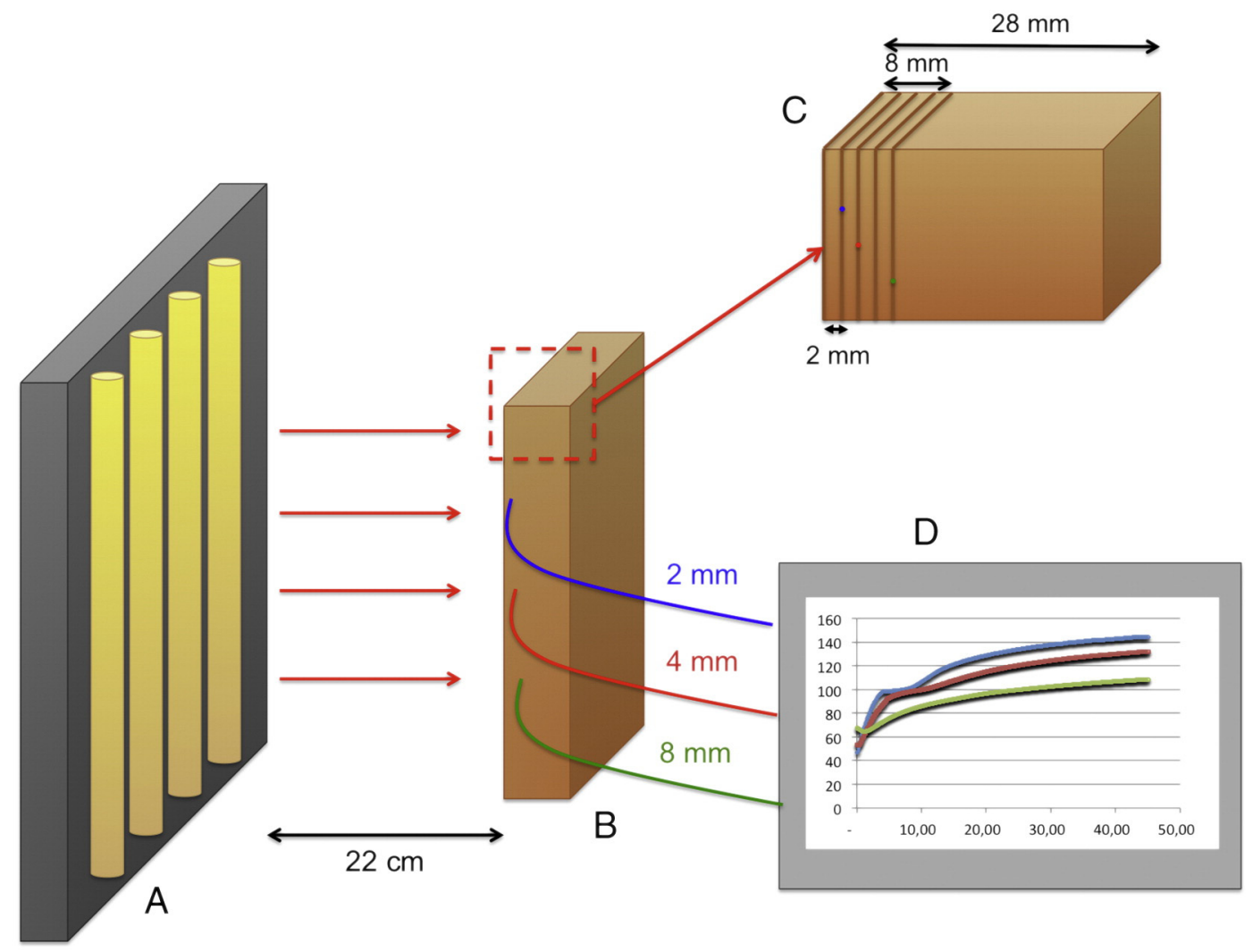

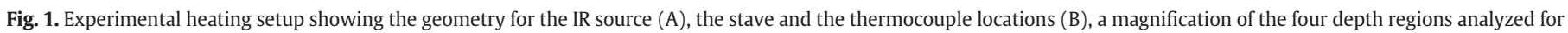
aroma extractability (C) and an example of temperature recordings (D). 
A

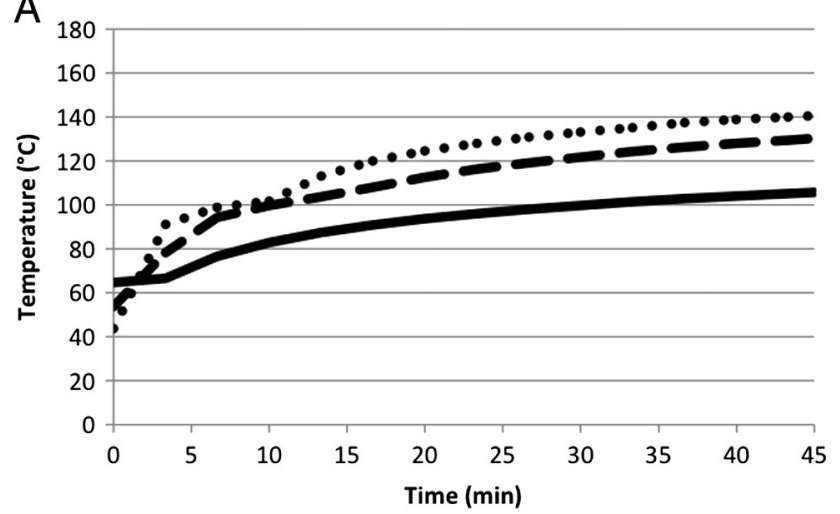

C

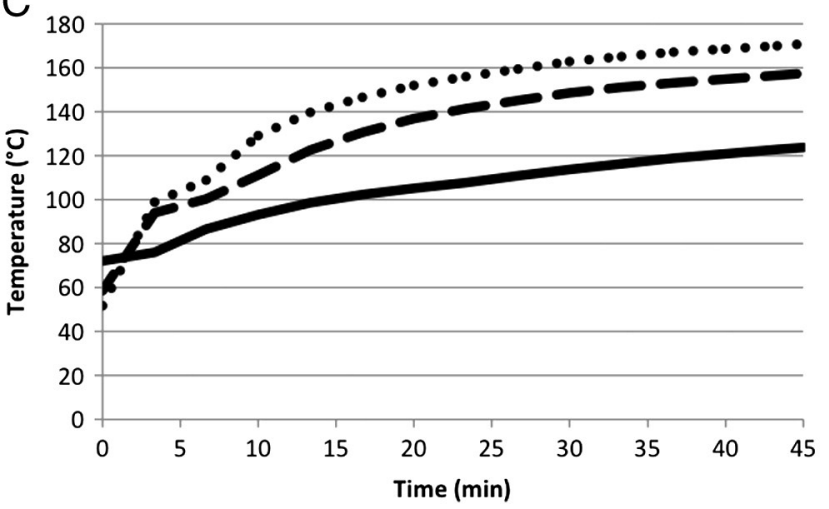

B

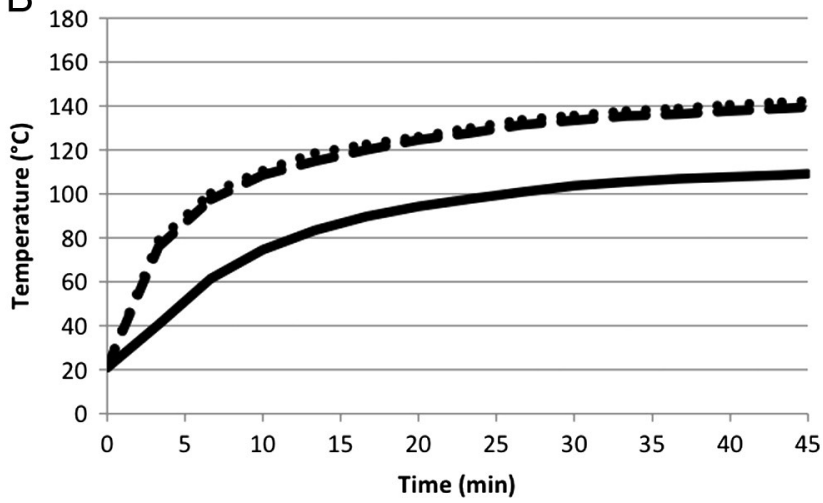

D

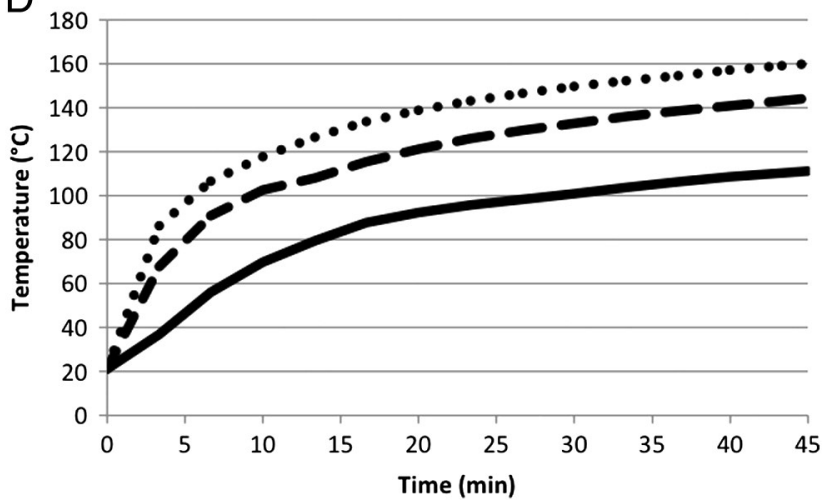

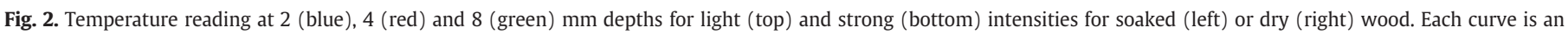
average over three repetitions. (For interpretation of the references to color in this figure legend, the reader is referred to the web version of this article.)

Therefore, and despite the fact that standard deviations for our measured guaiacol concentrations are witness to rather good repeatability (Fig. 3), we only kept the corresponding values as indications and did not consider them for the final discussion.

\subsection{Statistical analysis}

The data were statistically analyzed using the XLstat software (Addinsoft, 2011_1_03 version). The statistical significance of differences between the data was evaluated by analysis of variance followed by the Tukey test. A statistical difference was considered significant at $\mathrm{p}<0.01$. The distribution of concentrations for two of the six compounds studied here did not strictly satisfy to normality (guaiacol and vanillin). However, we considered that the test was robust enough to be used (Box, 1953). The principal component analysis (PCA) was done on mean concentration values for each condition (one condition corresponding to one intensity and one hydration state for a given depth) and we used the Pearson test conditions, which normalize the value.

\section{Results and discussion}

Literature data on the impact of heat treatments on the potentiality for volatile compound extraction are abundant for dry wood, although discrepancies can be easily found (Duval et al., 2013). In contrast very few studies have focused on the impact of the initial water content, and to the best of our knowledge, this is the first time that such prehydration process is evaluated under a model experiment, with the view to model volatile concentration gradients within the first $8 \mathrm{~mm}$ of wood exposed to heat (Fig. 1).

Fig. 2 compares the evolution of temperatures measured at three different depths for both light and strong heating and for dry and prehydrated wood. It appears that for the light treatment, maximum temperatures experienced by the wood after $45 \mathrm{~min}$ are roughly the same whether the wood was prehydrated or not, i.e. about 105,130 and $140{ }^{\circ} \mathrm{C}$ at 8,4 and $2 \mathrm{~mm}$ from the surface, respectively (Fig. 1). Most interestingly though, the surface temperature $(2 \mathrm{~mm})$ experienced by the soaked wood seems to be slightly higher than that experienced by the dry wood even if not significant (Supplementary Table A). Actually, major differences observed between dry and soaked woods concern the first 15 to 20 min of heating where the normal log-shape increase observed for the dry wood is interrupted by a plateau at $100{ }^{\circ} \mathrm{C}$ for the soaked wood, corresponding to the boiling point of adsorbed water within pores of the soaked wood. It must be noted that this plateau is not observed at an $8 \mathrm{~mm}$ depth, because the $100{ }^{\circ} \mathrm{C}$ temperature is slowly reached only after $30 \mathrm{~min}$ (Fig. 2). Another difference between the soaked and the dry wood is that for the former, initial temperatures are above those for the dry wood, consistently with the fact that the toasting process is run immediately after the soaking. Therefore, in contrast with the dry wood, the soaked wood does not have time to cool down before toasting, and this is all the more true for the $8 \mathrm{~mm}$ depth, where the starting temperature is about $15{ }^{\circ} \mathrm{C}$ above than that for the 2 and $4 \mathrm{~mm}$ depths.

Similar observations can be made for the strong heating (Fig. 2), even more pronounced when considering the final temperature, since after $45 \mathrm{~min}$ of heating, temperatures measured at any depth are higher in the soaked wood than in the dry wood $\left(+20^{\circ} \mathrm{C}\right.$, $+15{ }^{\circ} \mathrm{C}$ and $+10{ }^{\circ} \mathrm{C}$ about at 8,4 and $2 \mathrm{~mm}$, respectively). Therefore, a common feature to both the light and the strong heating is that prehydration favors heat transfers within the wood, in particular for heating temperatures above $100{ }^{\circ} \mathrm{C}$ where the temperature increase is faster for the soaked wood (Fig. 2). This is easily explained by the fact that during the $100{ }^{\circ} \mathrm{C}$ plateau, adsorbed water stores energy that is then released within the wood. To that respect, a prehydration 
Vanillin

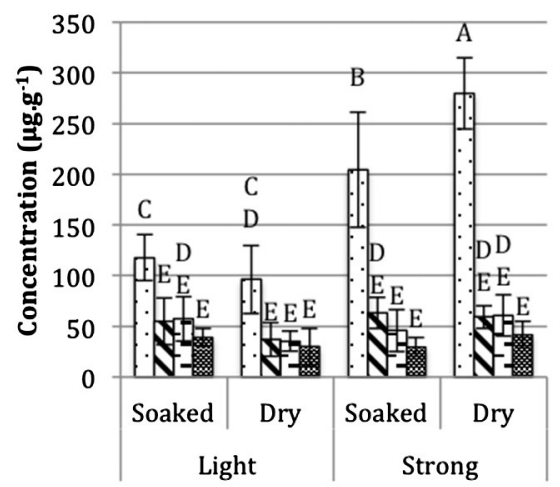

Eugenol

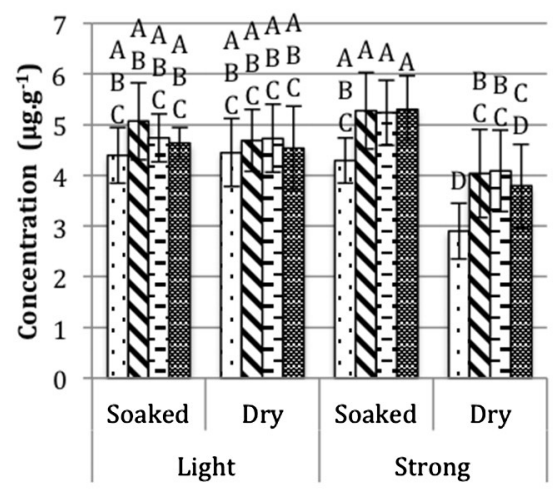

Cis-whisky lactone

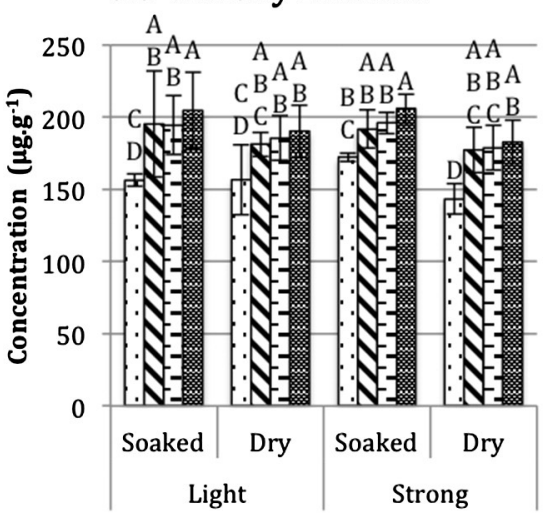

Guaïacol

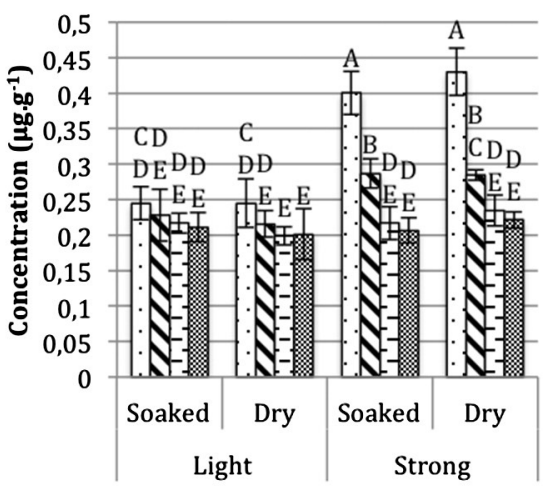

Furfural

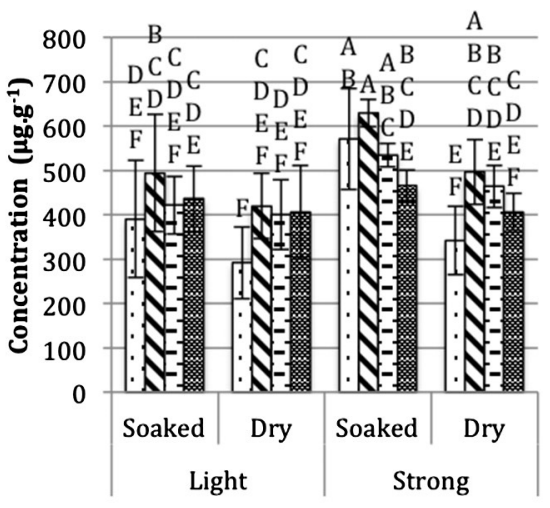

Trans-whisky lactone

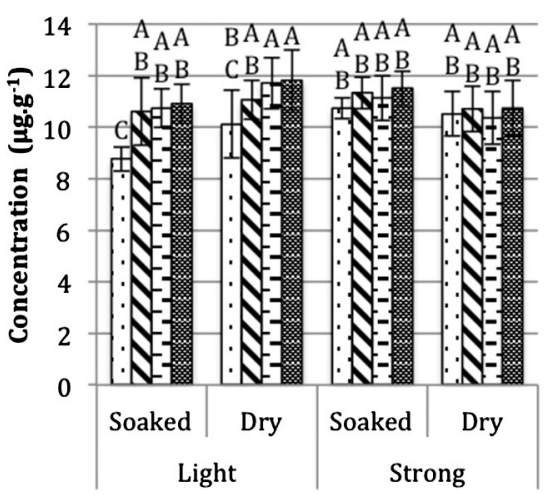

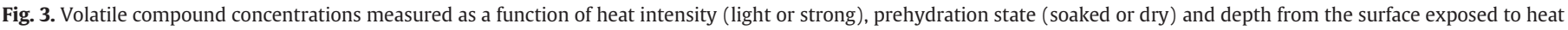
(point: 0-2 mm; slash: 2-4 mm; underscore: 4-6 mm; and the last one: 6-8 mm).

step of the wood such as done in this study, leads to a thermal behavior that contrasts with the traditional surface wetting of the wood during a fire heating, which decreases the surface temperature of the wood (Matricardi \& Waterhouse, 1999). Altogether, these observations indicate that if adsorbed water is supposed to have a delaying effect with respect to the thermal degradation of wood macromolecules (Canas, Belchior, \& Falcao, 2007) it can also promote higher transient local temperatures in the soaked wood and thus favor the formation of some wood-related aromas for the higher temperatures (Duval et al., 2013).

Concentration gradients within the first $8 \mathrm{~mm}$ for six wood-related aroma compounds are presented in Fig. 3. It clearly appears that for all of the compounds and whatever the treatment or the hydration state, no significant differences are observed between concentrations measured from 4 to $8 \mathrm{~mm}$ away from the surface. For the light treatment, statistically similar concentration values are already observed $2 \mathrm{~mm}$ away from the surface. Both observations suggest that under our conditions, heat treatments do not lead to significant concentration gradients beyond a certain depth $(2 \mathrm{~mm}$ and $4 \mathrm{~mm}$ for light and strong treatments, respectively), although temperature gradients within these widths can be as high as $40{ }^{\circ} \mathrm{C}$ (Fig. 2). It must be noted though, that even with a $40{ }^{\circ} \mathrm{C}$ gradient, this is consistent with our recent results which showed that heat treatments below $160{ }^{\circ} \mathrm{C}$ did not significantly modify extractable concentrations compared to those of unheated wood.

Fig. 4 shows the loading plot for the PCA analysis of all of mean values of concentrations in Fig. 3, where the first two components account for $81.51 \%$ of the total variability. This PCA highlights strong correlations between eugenol and cis-whisky lactone and strong anticorrelations with vanillin and guaiacol along the first component 
(59.39\% of the variability), whereas it shows a good correlation of furfural with the second component (22.13\% of the variability). trans-Whisky lactone, which displays correlations with both axes, is better correlated with the first one, thus with eugenol and cis-whisky lactone ( 0.603 for the first one against 0.341 for the second one). Considering Figs. 3 and 4 together, it appears that the six compounds studied here can be separated into three groups: vanillin and guaiacol which display an increase of the concentration (though limited to the first $2 \mathrm{~mm}$ ) with the heat intensity; at the opposite, eugenol and both whisky lactones which display constant concentrations or even a decrease; and furfural which displays constant concentrations except for the strong heat treatment of the soaked wood, which leads to the highest intensities within the first $4 \mathrm{~mm}$. These three groups provide an interesting illustration of the complex impact of heat and water on the extractability of aroma compounds. The first group clearly corresponds to thermally generated compounds (within the first $2 \mathrm{~mm}$ ) (Caldeira, Clímaco, De Sousa, \& Belchior, 2006; Campbell, Sykes, Sefton, \& Pollnitz, 2005; Fernández de Simón et al., 2010) and the adsorbed water acts as a buffer towards this thermal degradation of lignin, leading to a lower concentration in the soaked wood, although not significant for guaiacol (Fig. 3). However, as shown recently (Duval et al., 2013), such thermal degradation enhancement only occurs for temperatures of $200{ }^{\circ} \mathrm{C}$ or higher. Therefore, if temperatures experienced by the wood at $2 \mathrm{~mm}$ from the surface are of the order of $160{ }^{\circ} \mathrm{C}$ (Fig. 2) - preventing any significant thermal degradation deeper in the wood - it is likely that the wood actually experiences temperatures of the order or above $200{ }^{\circ} \mathrm{C}$ at its surface, leading to a gradient of more than $40{ }^{\circ} \mathrm{C}$ within the first $2 \mathrm{~mm}$ (for the strong treatment) (Chatonnet et al., 1989). If this first group behavior (vanillin and guaiacol) can be easily explained by the basic thermal degradation of lignin, the latter is not sufficient to explain the extractability observed for eugenol, which is also a product of lignin degradation, although it is microbially and/or enzymatically driven. Eugenol is indeed not thermally generated since its concentration does not significantly increase from the light to the strong treatment and even decreases for the strong treatment of the dry wood compared to that for the soaked wood (Fig. 3 and Duval et al., 2013). Therefore, within the frame of our experimental conditions, the behavior of the eugenol extractability could be considered to be driven mostly by an eugenol thermal degradation process for the dry wood. In contrast for the soaked wood, the adsorbed water would balance this thermal degradation by a slightly more efficient extraction process, possibly through a kind of steam distillation. As a result and for strong intensity treatments, soaked wood would exhibit higher concentrations than dry wood. Similar conclusions (though not so significant) could be proposed for the cis-whisky lactone. Finally, the behavior of furfural appears to be more complex since its production seems to be enhanced by the higher temperatures in the presence of adsorbed water. Since it has been shown that furfural arises from hemicellulose depolymerization and that its production is catalyzed by the acetic acid also formed during this degradation (Chatonnet et al., 1989), our results suggest that the presence of adsorbed water could promote the catalytic effect of acetic acid by enhancing its diffusion though the polymer network.

A projection of the 16 individuals on the 1-2 factorial plan is shown in Fig. 5, where different features can be observed. To guide eyes, groups of individuals for a given intensity of heat treatment $(\mathrm{L}=$ light; $\mathrm{S}=$ strong) and an initial state of wood ( $\mathrm{S}=$ soaked; $\mathrm{D}=$ dry) are materialized by lines. Fig. 5 clearly reveals that (i) for a given heat intensity, there is a parallel evolution for the dry and the soaked wood and (ii) for both intensities, concentration gradients through the first $4 \mathrm{~mm}$ of the wood depth are rather well explained by the first axis, although more significantly for the strong intensity. Another interesting feature in agreement with above comments - is the good correlation between the second axis and heat intensities, i.e. an increase in heat intensity is correlated with furfural production within the first $4 \mathrm{~mm}$ (see for instance from green to blue lines). Furthermore, in the case of the strong intensity and whether the wood has been soaked or not, concentrations beyond the first $4 \mathrm{~mm}$ are also well explained by the second axis, i.e. by

Variables (axes F1 et F2 : 81,51 \%)

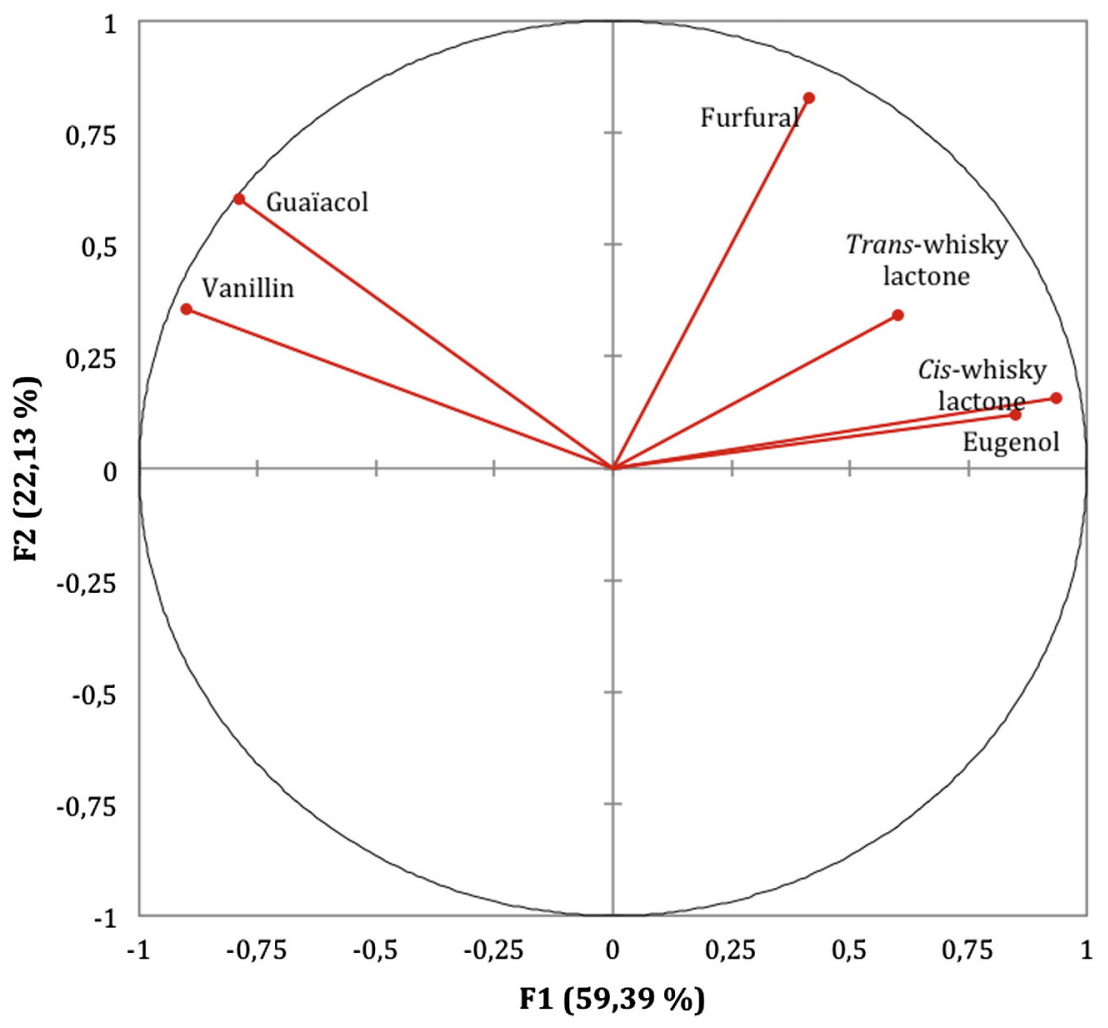

Fig. 4. Projection of composition data (variables) on principal components 1 and 2. 
Observations (axes F1 et F2 : 81,51\%)

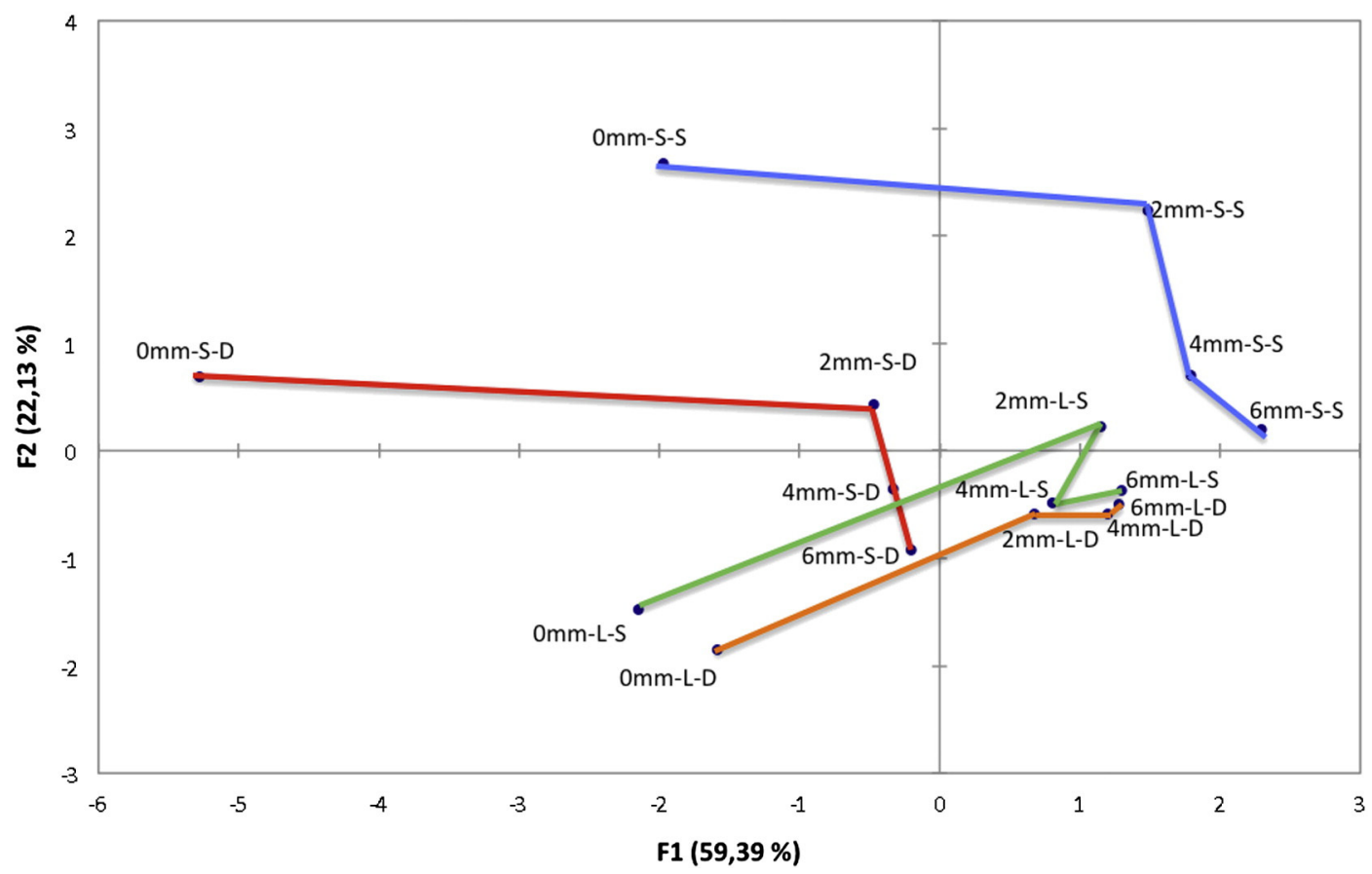

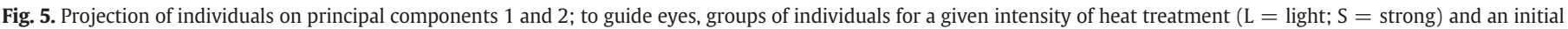

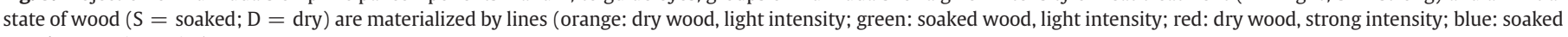
wood, strong intensity).

heat intensities. This is consistent with the fact that the deeper in the wood, the lower the temperature, and thus the lower the concentration in thermally generated compounds, including furfural. Basically, Fig. 5 shows that if a light treatment - equivalent to the AquaFlex treatment for a soaked wood (green line) - is applied to a dry wood (orange line), the major difference in aroma extractability only concerns the first $2 \mathrm{~mm}$, whereas concentrations deeper in the wood are not statistically different. In contrast, if wood contains preadsorbed water, strong heating - such as for the traditional toasting with dry wood (red line) would promote a higher furfural and whisky lactone aroma impact (blue line). Therefore, altogether these results show that if the AquaFlex® treatment certainly leads to a possible lower impact in wood aromas than the traditional toasting, mostly because of a lower impact of vanillin and guaiacol within the first $2 \mathrm{~mm}$, both the heat intensity and the initial composition have an important impact on the aroma extractability of cooperage wood.

Our results have shown that under our experimental conditions, whatever the heat intensity, temperatures experienced by the wood at $4 \mathrm{~mm}$ deep, regardless of its water content, are lower than $160{ }^{\circ} \mathrm{C}$. In agreement with our recently published results (Duval et al., 2013), this means that concentrations of all of the studied compounds deeper than $4 \mathrm{~mm}$ from the surface are the same as those in unheated wood. Therefore and considering that wine can diffuse as deep as $8 \mathrm{~mm}$ in the wood during barrel aging, our results emphasize the importance of the initial composition of wood on the impact that it can have on the wine (Gougeon et al., 2009).

\section{Conclusion}

Monitoring precisely the impact of cooperage bending and toasting processes on the extractability of oak wood aroma compounds during barrel aging of wines remains a challenge, and the scientific literature reports wide ranges of values for aroma concentrations measured in model or in real wines. For the first time using an IR heat source, we have applied two different controlled heat flux intensities on oak wood staves, either dry or previously soaked in hot water (AquaFlex process). We have compared hydroalcoholic extract concentrations of six wood-related aroma compounds (vanillin, furfural, eugenol, guaiacol and cis- and trans-whisky lactones) as a function of the depth of these staves. Concentrations of extractable compounds significantly varied as a function of heat fluxes and/or the initial water content, only for the first $2 \mathrm{~mm}$ depths. Vanillin and guaiacol are compounds typically produced by thermal degradation of lignin, i.e. their concentrations increased with heat treatment intensities, but more for dry than soaked wood. Eugenol, and to a lesser extent whisky lactones, behave like biogenesis compounds and their concentrations decreased with heat treatment intensities for dry wood, whereas they remained constant for soaked wood, i.e. the balance between extraction and degradation would have slightly been in favor of extraction. Finally, like guaiacol and vanillin, furfural is thermally generated through the degradation of the parent macromolecule (hemicellulose), but in contrast its generation was higher for the soaked wood. Therefore, modulating the extractability of wood aromas using prehydration requires that temperatures experiences by the wood during the toasting process are rigorously monitored.

Supplementary data to this article can be found online at http:// dx.doi.org/10.1016/j.foodres.2013.07.008.

\section{Acknowledgments}

We are grateful to the Conseil Régional de Bourgogne and the Tonnellerie Seguin-Moreau for their financial support and to Dr. Jordi Ballester for his assistance with the statistical analyses.

\section{References}

Alañón, M. E., Rubio, H., Díaz-Maroto, M. C., \& Pérez-Coello, M. S. (2010). Monosaccharide anhydrides, new markers of toasted oak wood used for ageing wines and distillates. Food Chemistry, 119(2), 505-512.

Ancín, C., Garde, T., Torrea, D., \& Jimenez, N. (2004). Extraction of volatile compounds in model wine from different oak woods: Effect of SO2. Food Research International, 37(4), 375-383. 
Cadahía, E., Fernández de Simón, B., \& Jalocha, J. (2003). Volatile compounds in Spanish, French, and American oak woods after natural seasoning and toasting. Journal of Agricultural and Food Chemistry, 51(20), 5923-5932.

Cadahía, E., Muñoz, L., Fernández de Simón, B., \& García-Vallejo, M. C. (2001). Changes in low molecular weight phenolic compounds in Spanish, French, and American oak woods during natural seasoning and toasting. Journal of Agricultural and Food Chemistry, 49(4), 1790-1798.

Caldeira, I., Clímaco, M. C., De Sousa, R. B., \& Belchior, A. P. (2006). Volatile composition of oak and chestnut woods used in brandy ageing: Modification induced by heat treatment. Journal of Food Engineering, 76(2), 202-211.

Campbell, J. I., Sykes, M., Sefton, M. A., \& Pollnitz, A. P. (2005). The effects of size, temperature and air contact on the outcome of heating oak fragments. Australian Journal of Grape and Wine Research, 11(3), 348-354.

Canas, S., Belchior, A. P., \& Falcao, A. (2007). Effect of heat treatment on the thermal and chemical modifications of oak and chestnut wood used in brandy ageing. Ciência e Técnica Vitivinicola, 22(1), 5-14.

Canas, S., Grazina, N., Belchior, A. P., Spranger, M. I., \& De Sousa, R. B. (2000). Modelisation of heat treatment of Portuguese oak wood (Quercus pyrenaica L.). analysis of the behaviour of low molecular weight phenolic compounds. Ciência e Técnica Vitivinicola, 15(2), 75-94.

Carrillo, J. D., Garrido-López, Á., \& Tena, M. T. (2006). Determination of volatile oak compounds in wine by headspace solid-phase microextraction and gas chromatography-mass spectrometry. Journal of Chromatography. A, 1102(1-2), 25-36.

Chatonnet, P., \& Boidron, J. (1989). Incidence du traitement thermique du bois de chêne sur sa composition chimique. 1ère partie: Définition des paramètres themriques de la chauffe des fûts en tonnellerie. Connaissance de la Vigne et du Vin, 23(2), 77-87.

Chatonnet, P., Boidron, J., \& Pons, M. (1989). Incidence du traitement thermique du bois de chêne sur sa composition chimique. 2ème partie: Évolution de certains composés en fonction de l'intensité de brûlage. Connaissance de la Vigne et du Vin, 23(4), 223-250.

Cutzach, I., Chatonnet, P., \& Dubourdieu, D. (1999). Study of the formation mechanisms of some volatile compounds during the aging of sweet fortified wines. Journal of Agricultural and Food Chemistry, 47(7), 2837-2846.

Del Alamo Sanza, M., Nevares Dominguez, I., Carcel Carcel, L. M., \& Navas Gracia, L. (2004). Analysis for low molecular weight phenolic compounds in a red wine aged in oak chips. Analytica Chimica Acta, 513(1), 229-237.

Doussot, F., De Jéso, B., Quideau, S., \& Pardon, P. (2002). Extractives content in cooperage oak wood during natural seasoning and toasting; influence of tree species, geographic location, and single-tree effects. Journal of Agricultural and Food Chemistry, 50(21), 5955-5961.

Doussot, F., Pardon, P., Dedier, J., \& De Jéso, B. (2000). Individual, species and geographic origin influence on cooperage oak extractible content (Quercus robur L. and Quercus petraea Liebl.). Analysis, 28(10), 960-965.

Duval, C. J., Sok, N., Laroche, J., Gourrat, K., Prida, A., Lequin, S., et al. (2013). Dry vs. soaked wood: Modulating the volatile extractible fraction of oak wood by heat treatments. Food Chemistry, 138(1), 270-277.

Fernández de Simón, B., Cadahía, E., Del Álamo, M., \& Nevares, I. (2010). Effect of size, seasoning and toasting in the volatile compounds in toasted oak wood and in a red wine treated with them. Analytica Chimica Acta, 660(1-2), 211-220.

Ferreira, V., Jarauta, I., López, R., \& Cacho, J. (2003). Quantitative determination of sotolon, maltol and free furaneol in wine by solid-phase extraction and gas chromatographyion-trap mass spectrometry. Journal of Chromatography. A, 1010(1), 95-103.

Feuillat, F., Keller, R., Sauvageot, F., \& Puech, J. -L. (1999). Characterization of French oak cooperage (Quercus robur L., Quercus petraea Liebl.). Research of the study group on barrel-aging burgundy wines. American Journal of Enology and Viticulture, 50(4), 513-518.
Fulcrand, H., Benabdeljalil, C., Rigaud, J., Cheynier, V., \& Moutounet, M. (1998). A new class of wine pigments generated by reaction between pyruvic acid and grape anthocyanins. Phytochemistry, 47(7), 1401-1407.

Fulcrand, H., Dos Santos, P. -J. C., Sarni-Manchado, P., Cheynier, V., \& Favre-Bonvin, J. (1996). Structure of new anthocyanin-derived wine pigments. Journal of the Chemical Society, Perkin Transactions 1(7), 735.

Garde-Cerdán, T., \& Ancín-Azpilicueta, C. (2006). Review of quality factors on wine ageing in oak barrels. Trends in Food Science \& Technology, 17(8), 438-447.

González-Marco, A., Jiménez-Moreno, N., \& Ancín-Azpilicueta, C. (2008). Concentration of volatile compounds in Chardonnay wine fermented in stainless steel tanks and oak barrels. Food Chemistry, 108(1), 213-219.

Gougeon, R. D., Lucio, M., De Boel, A., Frommberger, M., Hertkorn, N., Peyron, D., et al. (2009). Expressing forest origins in the chemical composition of cooperage oak woods and corresponding wines by using FTICR-MS. Chemistry (Weinheim an Der Bergstrasse, Germany), 15(3), 600-611.

Hale, M. D., Mccafferty, K., Larmie, E., Newton, J., \& Swan, J. S. (1999). The influence of oak seasoning and toasting parameters on the composition and quality of wine. American Journal of Enology and Viticulture, 50(4), 495-502.

Jarauta, I., Cacho, J., \& Ferreira, V. (2005). Concurrent phenomena contributing to the formation of the aroma of wine during aging in oak wood: An analytical study. Journal of Agricultural and Food Chemistry, 53(10), 4166-4177.

Kim, H. -S., Kim, S., Kim, H. -J., \& Yang, H. -S. (2006). Thermal properties of bio-flour-filled polyolefin composites with different compatibilizing agent type and content. Thermochimica Acta, 451(1-2), 181-188.

Matricardi, L., \& Waterhouse, A. L. (1999). Influence of toasting technique on color and ellagitannins of oak wood in barrel making. American Journal of Enology and Viticulture, 50(4), 519-526.

Mosedale, J. R., Feuillat, F., Baumes, R., Dupouey, J. -L., \& Puech, J. -L. (1998). Variability of wood extractives among Quercus robur and Ouercus petraea trees from mixed stands and their relation to wood anatomy and leaf morphology. Canadian Journal of Forest Research, 28(7), 994-1006.

Mosedale, J. R., Puech, J. -L., \& Feuillat, F. (1999). The influence on wine flavor of the oak species and natural variation of heartwood components. American Journal of Enology and Viticulture, 50(4), 503-512.

Perez-Prieto, L. J., López-Roca, J. M., Martínez-Cutillas, A., Pardo Mínguez, F., \& Gómez-Plaza, E. (2002). Maturing wines in oak barrels. Effects of origin, volume, and age of the barrel on the wine volatile composition. Journal of Agricultural and Food Chemistry, 50(11), 3272-3276.

Prida, A., \& Puech, J. -L. (2006). Influence of geographical origin and botanical species on the content of extractives in American, French, and East European oak woods. Journal of Agricultural and Food Chemistry, 54(21), 8115-8126.

Rentzsch, M., Schwarz, M., \& Winterhalter, P. (2007). Pyranoanthocyanins - An overview on structures, occurrence, and pathways of formation. Trends in Food Science E' Technology, 18(10), 526-534.

Sarni, F., Rabier, P., \& Moutounet, M. (1990). Fabrication des barriques et thermotraitements: relevé des températures. Revue française d'oenologie(123), 53-58.

Spillman, P. J., Pollnitz, A. P., Liacopoulos, D., Skouroumounis, G. K., \& Sefton, M. A. (1997). Accumulation of vanillin during barrel-aging of white, red, and model wines. Journal of Agricultural and Food Chemistry, 45(7), 2584-2589.

Towey, J. P., \& Waterhouse, A. L. (1996). The extraction of volatile compounds from French and American oak barrels in Chardonnay during three successive vintages. American Journal of Enology and Viticulture, 47(2), 163-172.

Waterhouse, A. L., \& Towey, J. P. (1994). Oak lactone isomer ratio distinguishes between wine fermented in American and French oak barrels. Journal of Agricultural and Food Chemistry, 42(9), 1971-1974. 